\title{
Manteniendo la excelencia en la revista FEM-Fundación Educación Médica
}

\author{
Arcadi Gual
}

El mundo editorial, en concreto el de las publicaciones de carácter científico como es FEM-Fundación Educación Médica, se ha visto afectado de forma especial por la aparición de las nuevas tecnologías, las nuevas formas de acceso y lectura de la actualidad científica, y los cambios en la distribución de la prensa escrita. Por todo ello, la revista FEMFundación Educación Médica, con el fin de cumplir mejor con sus propósitos fundacionales y dar un mejor servicio a la comunidad de habla castellana y portuguesa interesada en el área de la educación médica, introducirá a partir del volumen 18 del próximo año 2015 una serie de mejoras que queremos explicar en este editorial.

Durante 17 años, de forma ininterrumpida, la FEM ha dirigido, con el mismo formato y una periodicidad trimestral -primero con la cabecera $E d u$ cación Médica y actualmente como FEM-Fundación Educación Médica- una revista científica en lengua castellana en el área de conocimiento de la educación médica que está dispuesta a afrontar los retos que demandan los cambios sociales y siempre en la vía de la excelencia.

En primer lugar, la actual periodicidad trimestral (cuatro números anuales) pasará a tener un carácter bimestral (seis números anuales). Este incremento en la frecuencia de la publicación permitirá disminuir el lapso de tiempo entre la aceptación de un artículo y su publicación. Actualmente, este período oscila entre los seis y ocho meses, que sin duda debe considerarse demasiado prolongado para una revista científica. En este mismo sentido también se ha reestructurado todo el proceso editorial con un nuevo equipo de revisores, un Comité Editorial reformado y un equipo de dirección y de editores de sección completamente renovado. Es de justicia reconocer la capacidad técnica y las innumerables horas de dedicación que el equipo actual ha dedicado a la revista. La FEM quiere agradecer expresamente este generoso esfuerzo.

\section{Maintaining excellence in the journal FEM-Fundación Educación Médica}

The publishing world, and more particularly that of scientific publications like FEM-Fundación Educación Médica, has been hit especially hard by the appearance of the new technologies, new ways of accessing and reading about the latest emerging issues in science, and changes in the way the printed press is distributed. Accordingly, with the intention of complying better with its founding resolutions and offering a better service to the Spanish-and Portuguese-speaking community interested in the area of medical education, in 2015 as of volume 18 the journal FEM-Fundación Educación Médica will include a series of improvements that we wish to explain in this editorial.

The FEM has directed a scientific journal in Spanish uninterruptedly for the past 17 years - first with the name Educación Médica and now FEM-Fundación Educación Médica. Since it began it has had the same format, with issues devoted to the area of medical education appearing every three months, and it has always shown itself to be willing to face the challenges called for by the social changes taking place while at the same time constantly seeking excellence.

Firstly, the current three-monthly format (four issues per year) will become two-monthly (six issues a year). This increase in the frequency of publication will make it possible to reduce the time that elapses between acceptance of an article and its actual publication. At present, this period ranges from six to eight months, which is without a doubt too long for a scientific journal. In the same vein, the whole editorial process has been restructured with a new team of reviewers, a remodelled Editorial Board and completely overhauled teams of managers and section editors. It is only fair to acknowledge the technical capacity and countless hours of dedication that the current team has devoted to the journal. The FEM wishes to thank them expressly for their generous efforts.
Director de la revista FEM-Fundación Educación Médica. E-mail: agual@ fundacioneducacionmedica.cat (C) 2014 FEM 
Se ha pedido al nuevo equipo editorial que vele de forma especial por la excelencia científica de los artículos que se publiquen en la revista. Es necesario dar una vuelta de tuerca a la calidad de las publicaciones para acercarnos progresivamente al nivel de las revistas internacionales que lideran el área. Si en las diferentes áreas de conocimiento biomédico los investigadores de nuestro ámbito cultural compiten a la par con los investigadores del resto del mundo, hemos de esforzarnos para que también en el área de la educación médica lo hagan en las mismas condiciones.

A pesar del interés de la FEM en mantener la revista en el formato actual, las numerosas peticiones de una página web ágil, con acceso a la revista on line, nos ha decidido a abandonar el tradicional formato papel. Es evidente que esto supone una optimización de los costes, que incidían mayormente en la distribución y también, en menor medida, en el propio papel. En cualquier caso, el volumen 18 ya se encontrará accesible on line en una renovada página web de la revista (www.educmed.net) que se mantendrá de libre acceso durante todo el año 2015. El esfuerzo que la FEM y Viguera Editores realizarán con este cambio de formato se ha de entender no como una decisión meramente relacionada con el coste, sino fundamentalmente con la posibilidad de una mayor difusión, un mayor acceso y una mayor repercusión del contenido científico de la revista.

Estamos convencidos de que el mundo de habla castellana y portuguesa interesado en el ámbito de conocimiento de la educación médica entenderá los cambios previstos en la publicación, como así lo han hecho las instituciones nacionales e internacionales que auspician la revista (WFME, AMEE, FEPAFEM-PAFAMS, SEDEM, CDFM, COMB). Entre estas instituciones merece una especial mención la Sociedad Española de Educación Médica, que en su día decidió adoptar la revista como su órgano oficial de expresión y cuyas historias están tan estrechamente ligadas. Sin embargo, lo que pedimos a estas instituciones, y en especial a toda nuestra comunidad de educadores médicos, no es sólo su comprensión, sino su participación. Sin esta participación de los profesionales de nuestro entorno cultural, el camino hacia la excelencia de la educación médica no será fácil.
The new editorial board has been asked to take special pains to safeguard the scientific excellence of the articles published in the journal. The quality of the publications needs to be ratcheted up in order to gradually approach the level of the international journals that lead the field in this area. If the researchers in our cultural setting compete at the same level as researchers from around the world in the different areas of biomedical knowledge, we have to strive to ensure that in the area of medical education they do so under the same conditions.

Despite the FEM's interest in maintaining the present format of the journal, the numerous requests for a more dynamic website, with online access to the journal, have led us to abandon the traditional hardcopy paper format. It is obvious that this brings with it a streamlining of costs, which were mainly derived from distribution and also, although to a lesser extent, from the actual paper itself. In any case, volume 18 will already be accessible online at the journal's refurbished website (www.educmed.net), which will be free-access throughout the whole of 2015. The efforts that will be made by the FEM and Viguera Editores in carrying out this change of format must not be seen as just a cost-related decision but essentially as the chance to achieve more widespread diffusion, greater access and more repercussion of the scientific content of the journal.

We are convinced that the Spanish-and Portuguese-speaking world interested in the area of medical education will understand the changes foreseen in the publication, as has been the case of the national and international institutions that back the journal (WFME, AMEE, FEPAFEM-PAFAMS, SEDEM, CDFM, COMB). Among these institutions, special mention must go to the Sociedad Española de Educación Médica, which once took the decision to adopt the journal as its official mouthpiece and whose stories are so closely related. Nevertheless, what we ask from these institutions, and especially the whole of our community of medical educators, is not only your comprehension but also your participation. Without this participation by the professionals working in our cultural setting, the path towards excellence in medical education will by no means be an easy one to tread. 